\title{
The Use of Geotechnologies In the Environmental Vulnerability Diagnosed in Sustainable Use Conservation Unit
}

Siqueira, H.E. ${ }^{1}$, Pereira, G.T.2 ${ }^{2}$ Pissa rra, T.C.T. ${ }^{3}$, Valle J unior, R.F. ${ }^{4}$, Santi, G. L. D. ${ }^{5}$, Campos, C.A.A. ${ }^{6}$

${ }^{1}$ Doctorate in Agronomy (Soil Science)na Faculdade de Ciências Agrárias e Veteriná rias - FCAV-UNESP, Campus de J a botic a bal - SP, Bra sil.

2Prof. Dr. at the Faculda de de Ciências Agrárias e Veterinárias - FCAV- UNESP, Campus de J abotic a bal - SP, Brasil.

${ }^{3}$ Profa. Dra. at the Faculdade de Ciências Agrárias e Veterinárias - FCAV- UNESP, Campus de J aboticabal - SP, Brasil.

${ }^{4}$ Prof. Dr. at the Instituto Federal do Triângulo Mineiro - Campus Uberaba, MG, Brazil.

${ }^{5}$ Student in Geography at Universidade Federal do Triângulo Mineiro, Uberaba-MG, Brazil.

${ }^{6}$ Prof. Dr. of Universida de Federal do Triângulo Mineiro, Ubera ba-MG, Brazil.

Corresponding autor: hygorsiqueira@ya hoo.com.br, genertp@fc av.unesp.br, teresap@ fcav.unesp.br, renato@iftm.edu.br, giulia.deisanti@gmail.com, carlos.campo@uftm.edu

\section{Abstract}

The misuse of agric ultural a ctivities has been a cause for concern a s to the risks of contamination of soil and water, with possible health and environmental impacts. The objective of this study was to verify the enviro nmental vulnera bility of water reso urc es in the Environmental Protection Area of the Uberaba (APA). The condition of risk and fra gility that the environment is found was determined using the multic riteria modeling 
of morphometric parameters and soil occupation, and data a nalysis was performed in a geographic information system (GIS) platform. The intervening factors selected for a nalysis were: draina ge density, slope, soil classes, distance of water lines and land use and occupation. It was possible to jointly evaluate the different information plans and to generate from the multic riteria the vulnerability of the water resources in the APA.

Keywords: information system, morphometry, conservation planning, multiple criteria.

\section{Introduction}

Environmenta I vulnerability refers to the risk of degradation of the natural environment, related to soil erosion, loss of biodiversity, soil and water resources contamination and loss of vegetation cover exacerbated by anthropogenic factors, which may result in the loss of biodiversity and compromise the quality and quantity of na tural reso urces (COSTA et al., 2007).

Multic riteria decision modelling (MCE) based on the geographic information System is the basis of decision-making, and the weighted Linearcombination (WLC) is one of the basic methods, which makes Exchange of factors "with each other". Modeling is an important tool for the study of environmental a nalysis (VELDKAMP, LAMBIN, 2001). This methodology provides altemative techniques to incorporate decisions preferences in the environmental assessment process. Thus, the objective of the use of MCE model is to find solutions to the problems of decision making characterized by multiple alternatives, which can be evaluated by using decision criteria (PINTO, 2010, BOTTERO et al., 2013).

Fuzzy logic, drawn by Zadeh (1965) became an important topic of research during the Decade of 1980 for use in GIS and environmental a dequacy a nalysis. Consists in algebraic logic analyses of maps, sustained by the simila rity Bayesian probability and Boolean, generating maps by map cumulative algebra through the standardization of the variables used, converting the data values unique in fitness values to the desired purpose.

Several researches in different areas were developed using MCE. Such studies in a gric ulture (AKINCI et al.; 2013, DRAGINCIC et al.; 2015;), soil conservation and fitness (VALLE J UNIOR et al.; 2014;), irrigation (CHEN, PAYDAR 2012), conservation of water reso urces (VALLE J UNIOR et al.; 2015; CALIZAYA et al.; 2010), conservation of natural resources and forestry (Bottero et al.; 2013; KAYA and KAHRAMAN 2011), transport and industrial projects (MACHARIS et al. 2012), Ec onomic s (MARTIN-ORTEGA, BERBEL 2010; ZUBARYEVA et al.; 2012) a mong others, showed the functionality of the multi-criteria a nalysis in decision making in different applic ation a reas.

The APA of Uberaba River just had a recognition and concem in 2003, in which in the Alegria, this basin in the APA, there was a derailment of a freight train, and this accident is considered 
the la rgest environmental disa ster of the TriânguloMineiro until the present day. The charges were made up by the octanol $\left(\mathrm{C}_{8} \mathrm{H}_{18} \mathrm{O}\right)$, methanol $\left(\mathrm{CH}_{4} \mathrm{O}\right)$, ISO-buta nol $\left(\mathrm{C}_{4} \mathrm{H}_{10} \mathrm{O}\right)$ and potassium chloride $(\mathrm{KCl})$ in which, with the accident, an explosion occurred and which devastated more than 1000.0 m of native vegetation, as well as deposit and disperse more than $670 \mathrm{~kg}$ of contaminants in soil and water. Public water supply was intemupted for more than 5 days and it was decreed a State of public calamity. In this period the lack of water was supplied by water trucks, however, insuffic ient. More than 250,000 inhabitants were impacted by the lack of water due to this accident and the contamination of water resources.

The a im of this paper is to draw up the diagnosis of environmental vulnerability of water resources from the multi-criteria modeling of physical parameters and microbasin in the APA morphometric of Uberaba River, through the use of GIS.

\section{Area of study}

Their diagnosis of vulnerability of water intercepted by highways in Environmental Protection Area APA of Uberaba River (Figure 1) which is part of the Uberaba River basin, located between the geographical coordinates $19.51^{\circ}$ and $19.74^{\circ}$ South and 47.64 and $47.98^{\circ}$ West of $G$ reenwich in the city of Uberaba-MG.

With a total a rea of $525.27 \mathrm{~km}^{2}$, the APA of Uberaba River has 62 mic roba sins, bounded from the main course, which contribute significantly to the quantity and quality of water reso urc es which supplies the city of Uberaba.

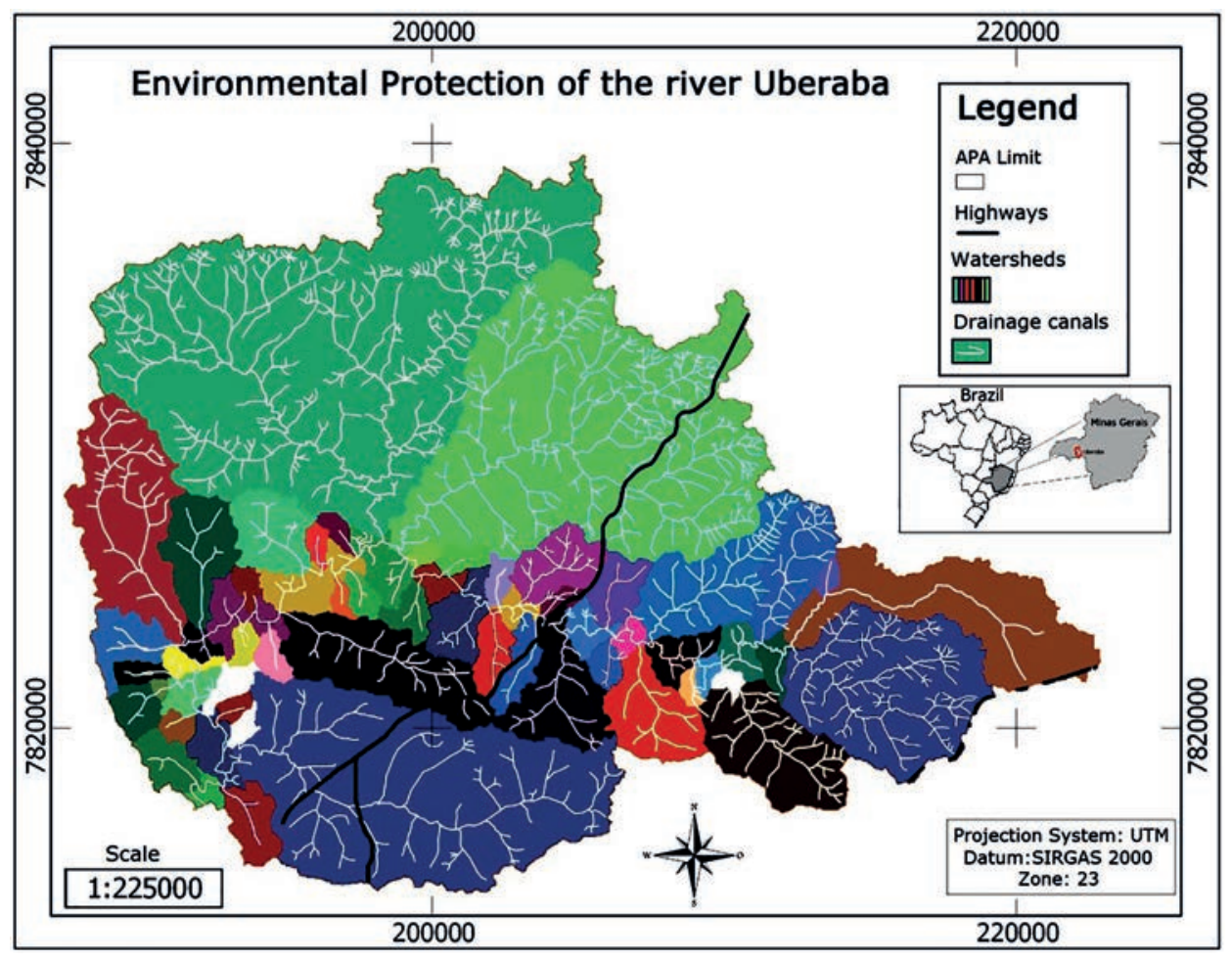

Figure 1 - APA of Uberaba River. Source: Siqueira. 
The climate of the region is classified according to the Köppen type Aw-hot humid tropical, with cold winter and dry, being the domain ranking the humid clima te with 4 to 5 dry months (ABDALA, 2012). The average annual precipitation varies between 1300 and $1700 \mathrm{~mm}$ in the rainy period corresponds to the warmest period of the year. Therefore, there is a characteristic ra iny scheme from October to March and a dry season from April to September. The months of December and J anuary are the rainiest.

The munic ipality of Uberaba is located in Sandstone Plateau Basalt relief of the Paraná basin with soil showing varied characteristics. Most have average texture, ranging from sandy to clay and are classified, in general, as the presence of mic roaggregates showing varying degrees of fertility, with a predominance of Red La tosol Distroférrico medium-textured, Red La tosol typic al and Acrisol Red-Yellow La tosol (NISHIYAMA, 1998).

Cruz (2003) points out that the topography is characterized by flat or slightly wa vy surfa ces, geologic ally formed by sedimentary rocks, basic ally the sandstone, the Cretaceous Bauru formation.

\section{Materials and Methods}

Multi-Criteria Analysis

The Idrisi G IS features integrated image processing feature for analysis and visua lization of spatial data, developed by resea rc hers at CLARK LABS, Depa rtment of geography, Clark University, Worc ester,
MA. In a ddition to the GIS a nalysis modules, image processing, surface analysis, change and time series a nalysis and modeling, the Idrisi providesa set of useful tools to support the decision-making process. In particular, it provides functions to implement the objective evaluation weighting procedure multi-criteria, standardization and diffuse set of criteria for aggregation. The Weighted Linear combination (WLC) present in the module, multiple criteria evaluation (MCE) of Idrisi J ungle, made it possible for this type of work (EASTMAN, 2012).

Second Malc zewski (1999) and Garfi et al., (2011), multic riteria methodology, the developed model follows three phases: (1) selection of the criteria (factors and constraints) for the a nalysis a nd creation of raster maps; (2) a ssignment of weight to each criterion; (3) combination of criteria and creating the final suitability map. In general the methodological process of multi-criteria analysis can be observed as shown in Figure 2.

\section{Data acquisition and choice of factors and constraints}

It was determined for this study of environmental vulnerability of water resources in APA of Uberaba River the acquisition and preparation of thematic mapping of physical factors and watershed morphometric totaling 5 (five) factors (dra inage density, distance from watercourses, slope of the land, use and occupation of the soil and soil classes) and 1 (one) constra int (dra ina ge networks). The restriction was used to the water courses were not classified in classes of vulnera bility. 


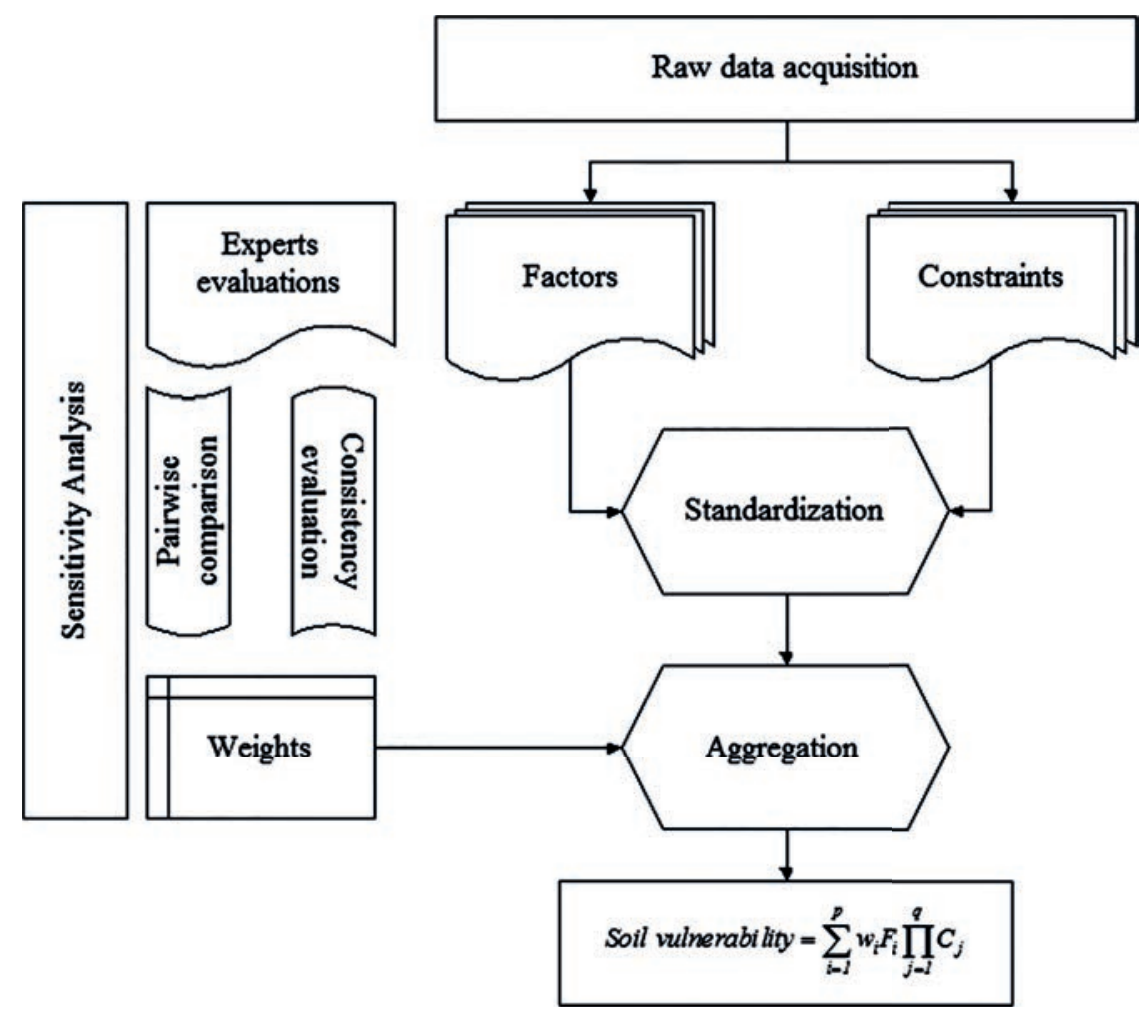

Figure 2-Methodological process of multi-criteria analysis. Source: Adapted from Siqueira et al. (2017).

The map of the drainage network (Figure 3 ) in the a rea under study was drawn from the Digital Elevation Model-DEM, rendered image of the Aster GDEM Sensor (Digital G lobal Elevation Model), at the geographic information System - GIS. The vector file of drainage was exported to the "Google Earth", which has made checking and modific ation, when necessary, of the respective watercourses. Subsequently, exported the vectorfile (drainage network) for the GIS Idrisi J ungle, being this the Cartographic base for the development of the database.

The demarcation of the mic robasin of the study a rea were performed from the DEM, in GIS Id risi J ungle, through the "Watershed". Once generated the information flow was traced the point closest to the exhilarating (mouth) of each watershed with the main course of the Uberaba River and using "Watershed" was bounded each hydrographic watershed.

Dra inage density corresponding to relative to the total length of the channels $(\Sigma \mathrm{L})$ in $(\mathrm{km})$ and the area of the watershed $(A B H)$ in $\left(\mathrm{km}^{2}\right)$ (C HRISTO FO LETT, 1980), was calculated on the following formula:

$$
D d=\sum L / A B H \quad \text { Eq. } 1
$$




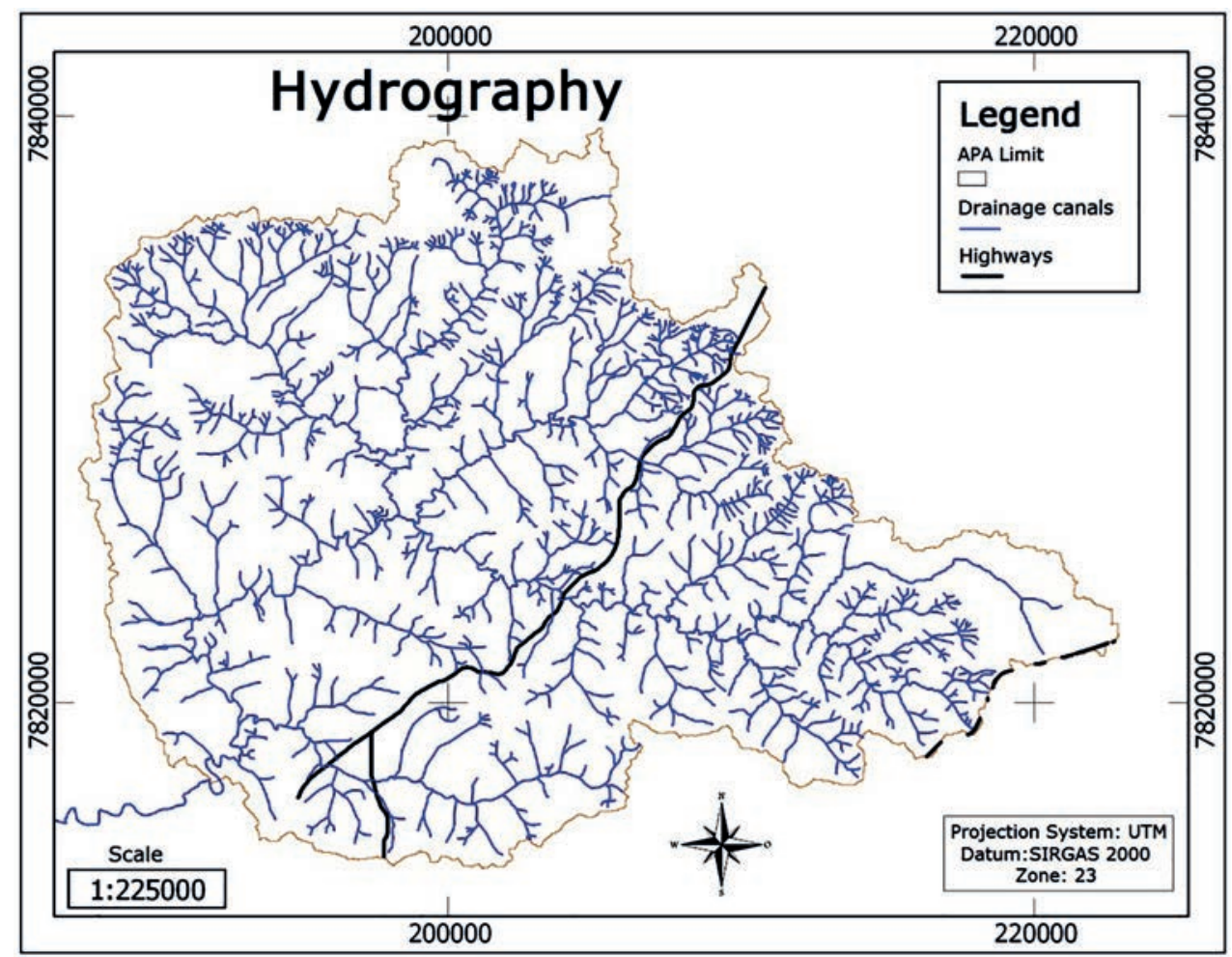

Figure 3 - Map of the APA of Uberaba River drainage.

The data were obtained from the morphometric study of the APA of Uberaba River mic robasin. Using vector files of drainage networks and proceeded to read of the lengths of each strand of mic robasins in AutoCad softwa re by the command "Modify-Lengthen." The a rea of the basin was a utomatically calculated in the GIS with the tool "area".

The values of the density of each drainage basin of the APA were classified according to the criteria described by Vilela and Mattos (1975), such that the ind ex of Dd varies from $0.5 \mathrm{~km} . \mathrm{km}^{-2}$, for with poordrainage basins, the 3.5 ormore, for exceptiona lly well dra ined basins. Wa sheld on Standardization of information plans where the drainage density values were rec lassified as shown in Figure 4.

The map of the distance from the waterline (Figure 5), drawn from the dra inage networks, originated from GIS Idrisi J ungle by distance operation menu "Buffer". Generated from the "Buffer" command the matrix file from distances of $30,50,100,150$ and 200 meters.

The map of slope land was drawn from the DEM where was applied in the GIS image clipping of the study a rea. With the use of the "Slope" tool in the GIS were generated in percentages the land slope classes. After raised the percentages of dec livity was conducted the reclassific ation 
of slope classes using the reference ranges of EMBRAPA (1999) described in Table 1 and illustrated in Figure 6.

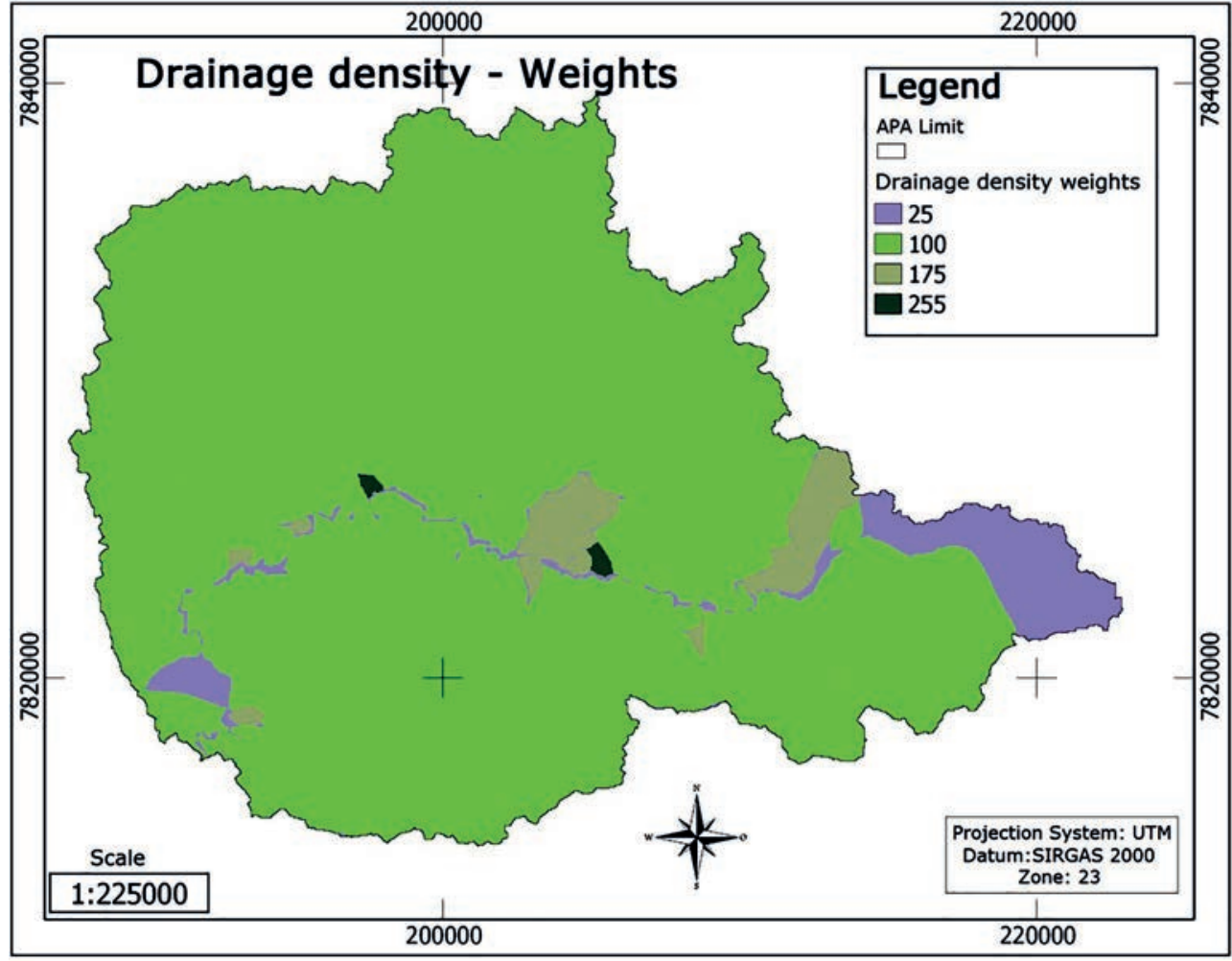

Figure 4-Map of drainage density of the APA of Uberaba River.

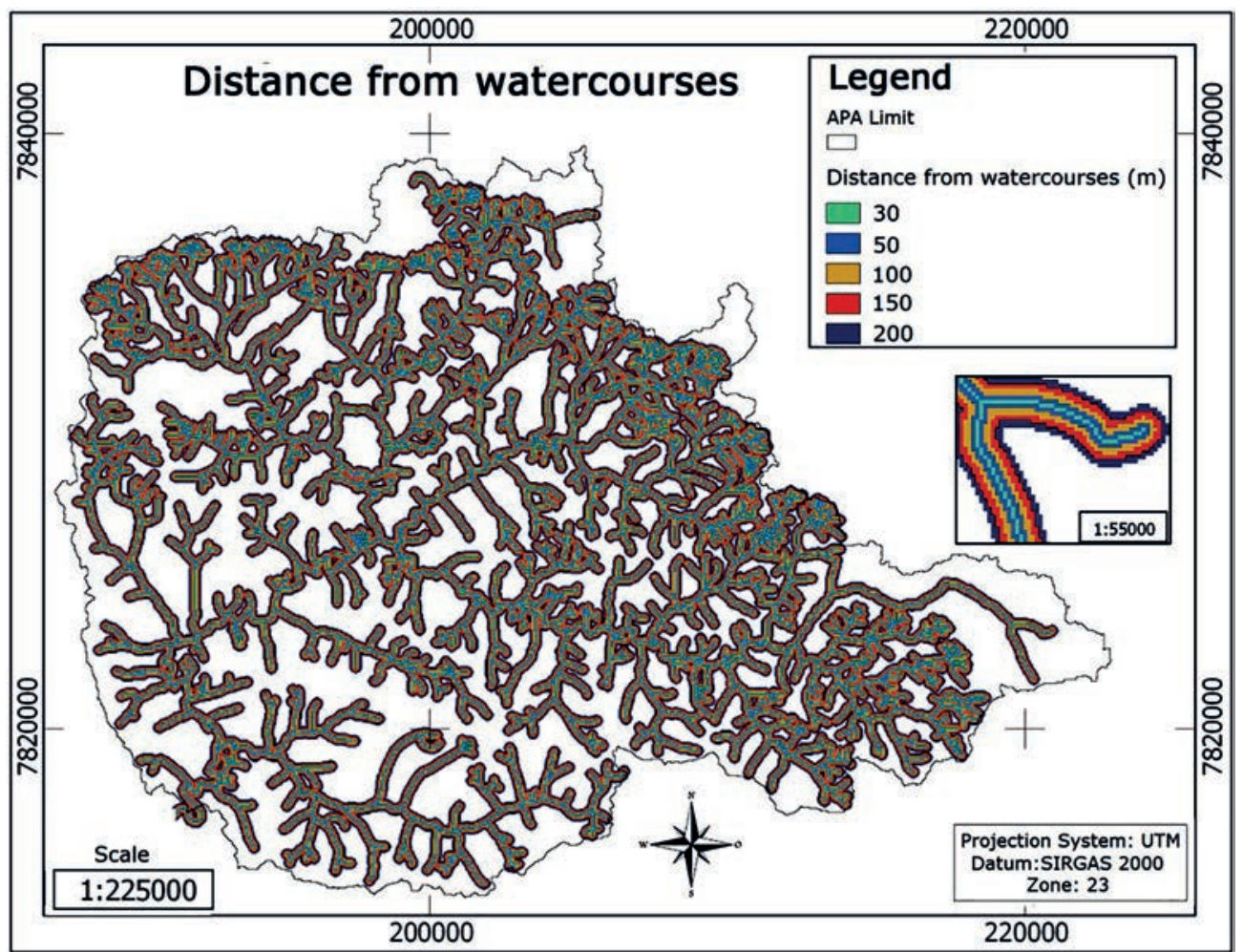

Figure 5 - Map of the distance from the waterline. 
Table 1 - Class intervals of slope and its corresponding reliefs.

\begin{tabular}{cc}
\hline Slope & Discrimination \\
\hline $0-5$ & Relief plan the gentle wavy \\
\hline $5-10$ & Gently rolling relief the wavy \\
\hline $10-20$ & Wavy to moderately undulating relief \\
\hline $20-47$ & The rugged mountainous relief \\
\hline$>47$ & Mountainous relief \\
\hline
\end{tabular}

Source: EMPRAPA (1999).

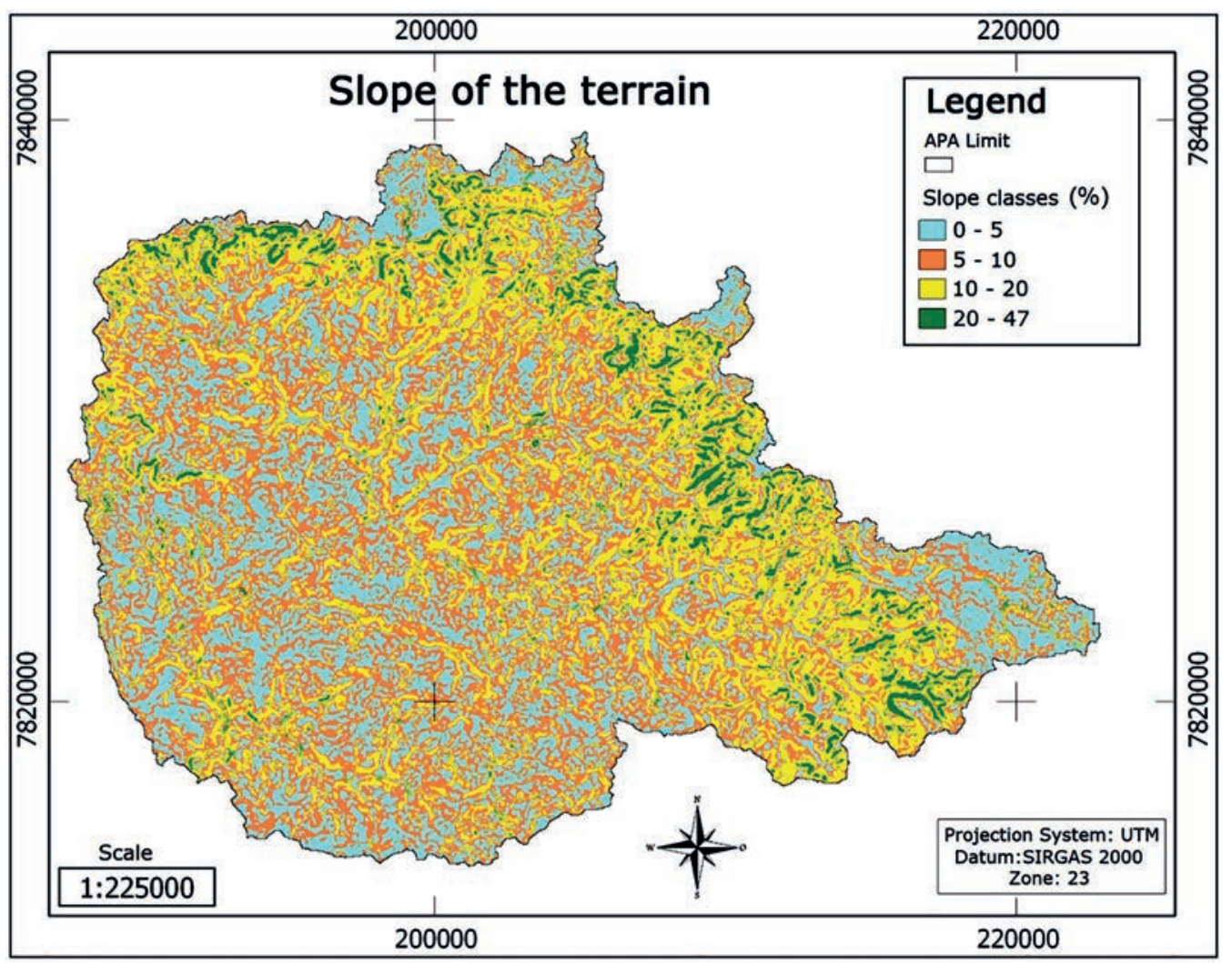

Figure 6 - Map of declivity of the APA of Uberaba River.

The map of soil use and occupation (Figure 7) has been developed using the supervised classific ation with use of the tool "Maxlike" of the GIS were used images from the Land sat 8 sa tellite Sensor "OLI-TIR" collected by the geological survey of the United Sta tes dated 06 February 2014, with spectral resolution of 30 metres. Were used for the colour composition bands 4 (R), 3 $(G)$ and 2 (B) in which these scenes were cut individually in GIS. Following devised the Landsat 8 RG B composition with the use of "Composite" tool. Were classified as to the use of the soil the following vegetable toppings: pasture, forests and annual crops.

The map of soil classes was generated from the cut in the soil of the State of Minas Gera is provided by UFV et al. (2010), illustrated in Figure 8. 


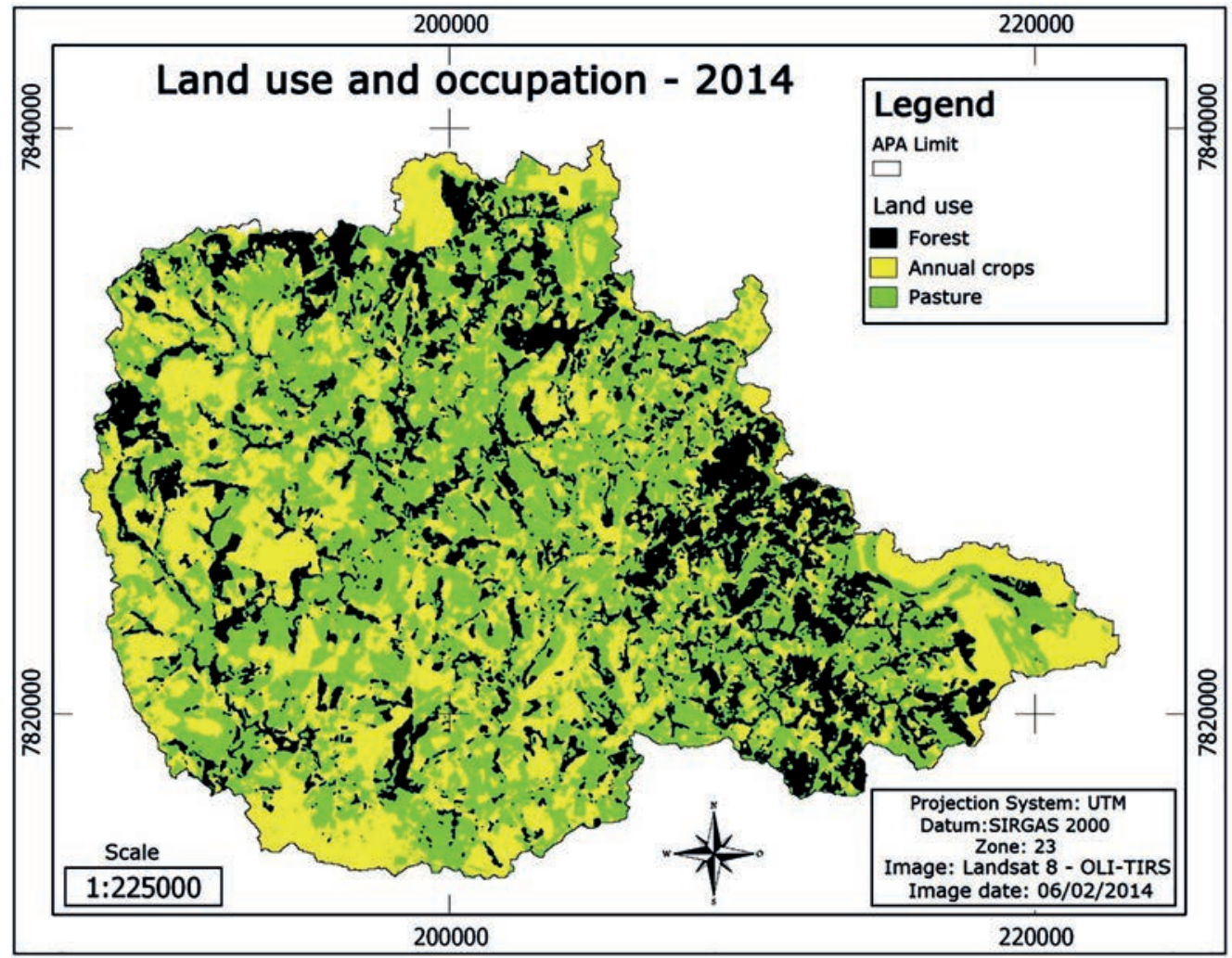

Figure 7 - Map of soil use and occupation of the APA of Uberaba River (2014).

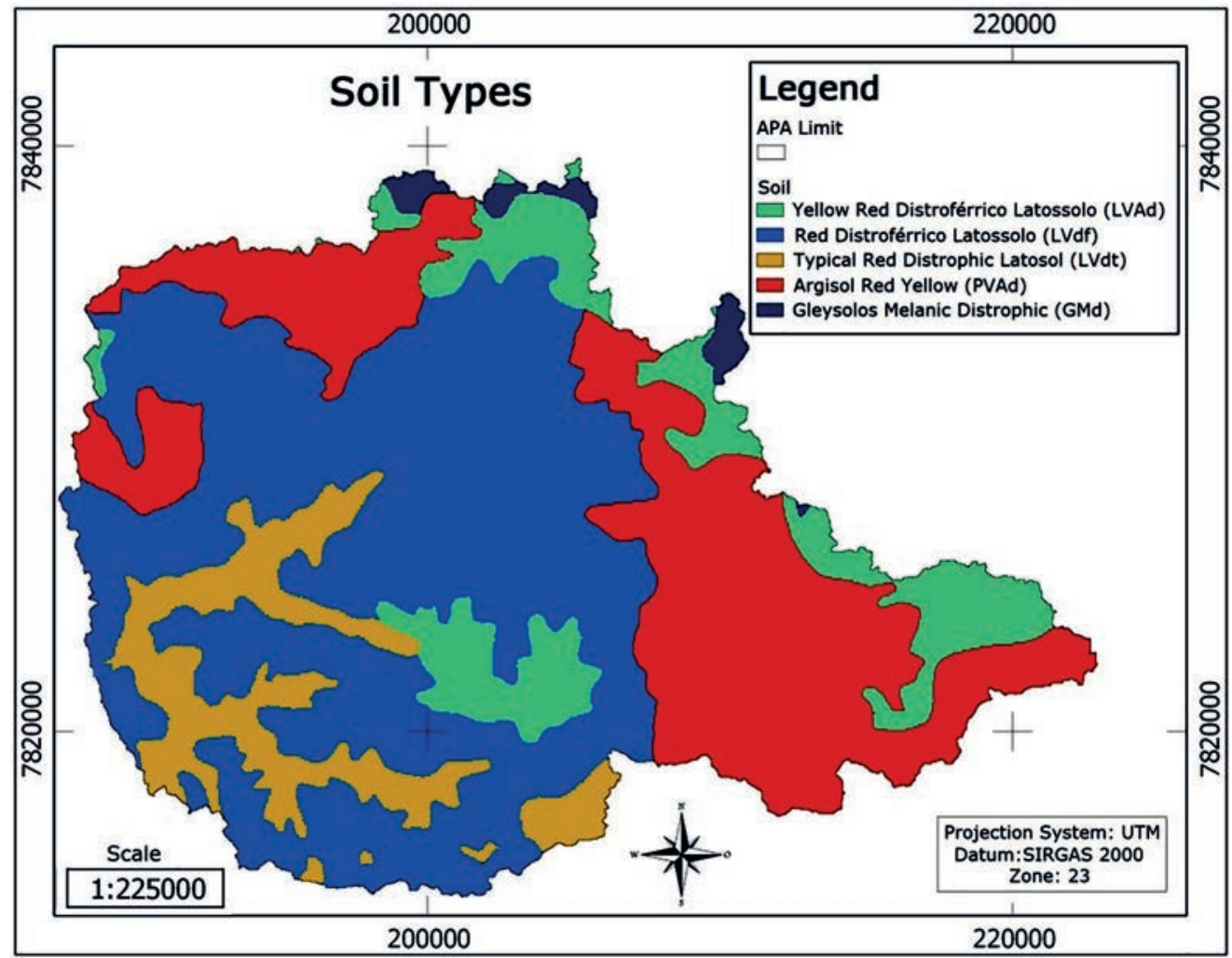

Figure 8 - Map of soil classes of APA of Uberaba River. 
The maps generated in this study a dop ts the system of Universal Tra nsverse Mercator projection (UTM); 23 zone; Datum horizontal a lignment 2000 SIRG AS (Geocentric Reference System for the Americas).

\section{Standardization}

The sta ndardization of the criteria analyzed followed a byte-level range ( 0 to 255), assigning the level 0 less importance and 255 greater importance. The construction of decision rule was executed by means of the functions of relevance to the whole "fuzzy". The slope, dra ina ge density, distance of water courses, classes of soil and the use and occupation of the soil were analyzed as continuous maps in "raster" format.

\section{Sensory analysis and assignment of weights}

Possession of the structured criteria in database in GIS, sensory a nalysis of these c riteria, which consisted of bibliographic surveys and discussions with multid isc ip lina ry tea $m$ about the importance of each factor in the process of vulnerability of water resources. Sought in the disc ussions with the various forms of interpretation and of valuesassignments and importance in the different criteria used in these studies (Table 2).

Importance values used in this study was also observed in research developed by Abbaspour et al. (2011), Pinto (2010) and
Valle J unior (2014) rela ted to environmental vulnera bility.

Depending on the use of several factors for surface a na lysis of wa ter reso urces vulnerability and whereas these have different weights in the decision-making process was established the routine WEIG HT (“Weighted Linear Combination"-WLC) from IrisDRISI, a weighting of va riables, according to your degree of relative importance on the decision. Through a paired comparison technique, developed by Sa aty (1980), in the context of a decision-making process known as a na lytic hiera rc hy process (AHP), which consists of the categorization problem in linear hiera rchical levels of importance in relation to each environmental factor (Table 3 ).

Based on the scale of comparators in Id risi were adopted 3 (three) different weighting factors scenarios by assigning greaterimportance to the criterion value of slope of the land (scenario 1), drainage density (scenario 2) and soil class 3 scenario (Table 4). This procedure was used to compare and id entify, after the assignment of weights in different scenarios, which c riteria indic a tes the a reas of vulnerability of water resources.

The routine of the MCE of Id risi, once assigned importance values, determined the sta tistic al weights for each factor (Table 4) and calculated the consistency index.Indicates the probability of the consistency of the points a rray to be generated at random and shall be less than 0.1 for model be considered accepTable (EASTMAN, 2012). 
Table 2 - Criteria identified for the study of environmental vulnerability.

\begin{tabular}{|c|c|c|}
\hline Criteria (factors) & Assigned & Values \\
\hline \multirow{5}{*}{ Drainage density $\left(\mathrm{Km} / \mathrm{Km}^{2}\right)$} & Too Low & 5 \\
\hline & Low & 25 \\
\hline & Media & 75 \\
\hline & High & 125 \\
\hline & Too high & 255 \\
\hline \multirow{5}{*}{ Away from the water lines (m) } & Distance $(30 \mathrm{~m})$ & 255 \\
\hline & Distance $(50 \mathrm{~m})$ & 175 \\
\hline & Distance (100 m) & 115 \\
\hline & Distance (150 m) & 75 \\
\hline & Distance (200 m) & 50 \\
\hline \multirow{5}{*}{ Slope of the land (\%) } & Slope (0 to $5 \%$ ) & 25 \\
\hline & Slope (5 to $10 \%$ ) & 75 \\
\hline & Slope (10 to $20 \%$ ) & 125 \\
\hline & Slope (20 to $47 \%$ ) & 175 \\
\hline & Slope $(47 \%)>$ & 255 \\
\hline \multirow{3}{*}{ Soil class } & $\begin{array}{l}\text { The presence of } \\
\text { microaggregates }\end{array}$ & 100 \\
\hline & Argissolos & 200 \\
\hline & Gleyssolos & 255 \\
\hline \multirow{3}{*}{ Soil use and occupation } & Forest Fragments & 255 \\
\hline & Pasture & 125 \\
\hline & Annual Crops & 75 \\
\hline
\end{tabular}

Table 3 - Scale of comparators with the respective weights of importance - fundamental Scale Saaty (1980).

\begin{tabular}{cc}
\hline Values & Mutual importance \\
\hline $1 / 9$ & Extremely less important than \\
\hline $1 / 7$ & Very strongly less important than \\
\hline $1 / 5$ & Strongly less important than \\
\hline $1 / 3$ & Moderately less important than \\
\hline 1 & Equally important to \\
\hline 3 & Moderately less important than \\
\hline 5 & Strongly more important than \\
\hline 7 & Very strongly more important than \\
\hline 9 & Extremely important that \\
\hline
\end{tabular}

Source: Saaty (1980). 
Table 4 - Paired comparison matrix which is part of the analytic hierarchy process-AHP (SAATY, 1980).

\begin{tabular}{lcccccc}
\hline & $\begin{array}{c}\text { Distance from } \\
\text { watercourses }\end{array}$ & $\begin{array}{c}\text { Use of } \\
\text { soil }\end{array}$ & $\begin{array}{c}\text { Soil } \\
\text { class }\end{array}$ & $\begin{array}{c}\text { Slope of } \\
\text { the land }\end{array}$ & $\begin{array}{c}\text { Drainage } \\
\text { density }\end{array}$ & Weight \\
\hline $\begin{array}{l}\text { Distance from } \\
\text { watercourses }\end{array}$ & 1 & $1 / 3$ & $1 / 5$ & 1 & 1 & 0.0863 \\
\hline Use of soil & 3 & 1 & $1 / 3$ & $1 / 5$ & 1 & 0.2702 \\
\hline Soil class & 5 & 3 & 1 & $1 / 3$ & $1 / 5$ & 0.4658 \\
\hline Slope of the land & 1 & $1 / 3$ & $1 / 5$ & 1 & $1 / 3$ & 0.0863 \\
\hline Drainage density & 1 & $1 / 5$ & $1 / 3$ & 1 & 1 & 0.0913 \\
\hline
\end{tabular}

The AHP was implemented by the module of weight of the IDRISI J unglesoftware. To this set of factors, the consistency index calculated was 0.07 in sc enario 1 , 0.07 in scenario 2 and 0.04 in scenario 3 considered acceptable for all scenarios adopted.

\section{Aggregation}

The data were aggregated on weighted linear combination (WLC) ("Weighted Linear Combination") of the Idrisi, considering their respective weights resulting in a map from 0 to 255 . It was nec essa ry to combine the data, in order to achieve the General map of vulnerability. In thiscase, a weighted linear combination was used, which combined the criteria and restriction maps according to the following formula:

$$
S j=(\Sigma W i X i) \Pi(C k)
$$

Eq. 2

Where:

Sj: $\quad$ represents the risk to pixel j;

Wi: represents the weight of the factori;

Xi: represents the criterion score of factori;

Ck: represents the constra int criteria score kand;

$\Pi: \quad$ is the symbol of the product.

The factors were combined in applying weights following a dequacy calculated from the product factors to the restric tions. The map was reclassified (Table 5) in five c lasses of vulnera bility of wa ter reso urces: Invulnerable, Modera tely Vulnerable, Vulnerable, Heavily Vulnerable and extremely vulnerable and their respective a rea s were spatialized and calculated. 
Table 5 - Range defined for classifying degree of vulnerability.

\begin{tabular}{lc}
\hline \multicolumn{1}{c}{ Risk classes } & Range of Classes \\
\hline Invulnerable & $0-50$ \\
\hline Moderately Vulnerable & $50-100$ \\
\hline Vulnerable & $100-150$ \\
\hline Heavily Vulnerable & $150-200$ \\
\hline Extremely Vulnerable & $200-255$ \\
\hline
\end{tabular}

Results and

Discussion

\section{Sensitivities of} the factors and

assignment of

\section{weights}

The importance of soil class, fator weights were the 0.0863 (distance of watercourses), 0.2702 (soil use and occupation), 0.4658 (soil class), 0.0863 (slope of the land) and 0.0913 for dra ina ge density; being the relationship of consistency of $4 \%$. However, for similar weights for the same sc enario 3 noted that the consistency index was the sa meobtained by (VALLE J UNIOR et al. 2014). In this manner, appending the drainage density factor the consistency index remained the same.

\section{The vulnerability in the APA}

The map of vulnerability of water resources based on weighted linear combination (Eq . 2) of the factors referred to above is illustrated in Figure 9, with the values of the vulnerability described in the Table 6 . The results of the vulnerability represent am the high potential risk of contamination of water resources therefore strongly c lasses and extremely vulnerable occupy a portion of (16.39\%, $7.12 \%)$ of the APA and the vulnerable class (49.89\%) total $73.4 \%$. The most plausible cause for this fact is the occupation of the areas G leysolos, Argissolos and the presence of Mic roaggregates coupled with land use factor tha twerec la ssified with a very high note until 255 byte. 


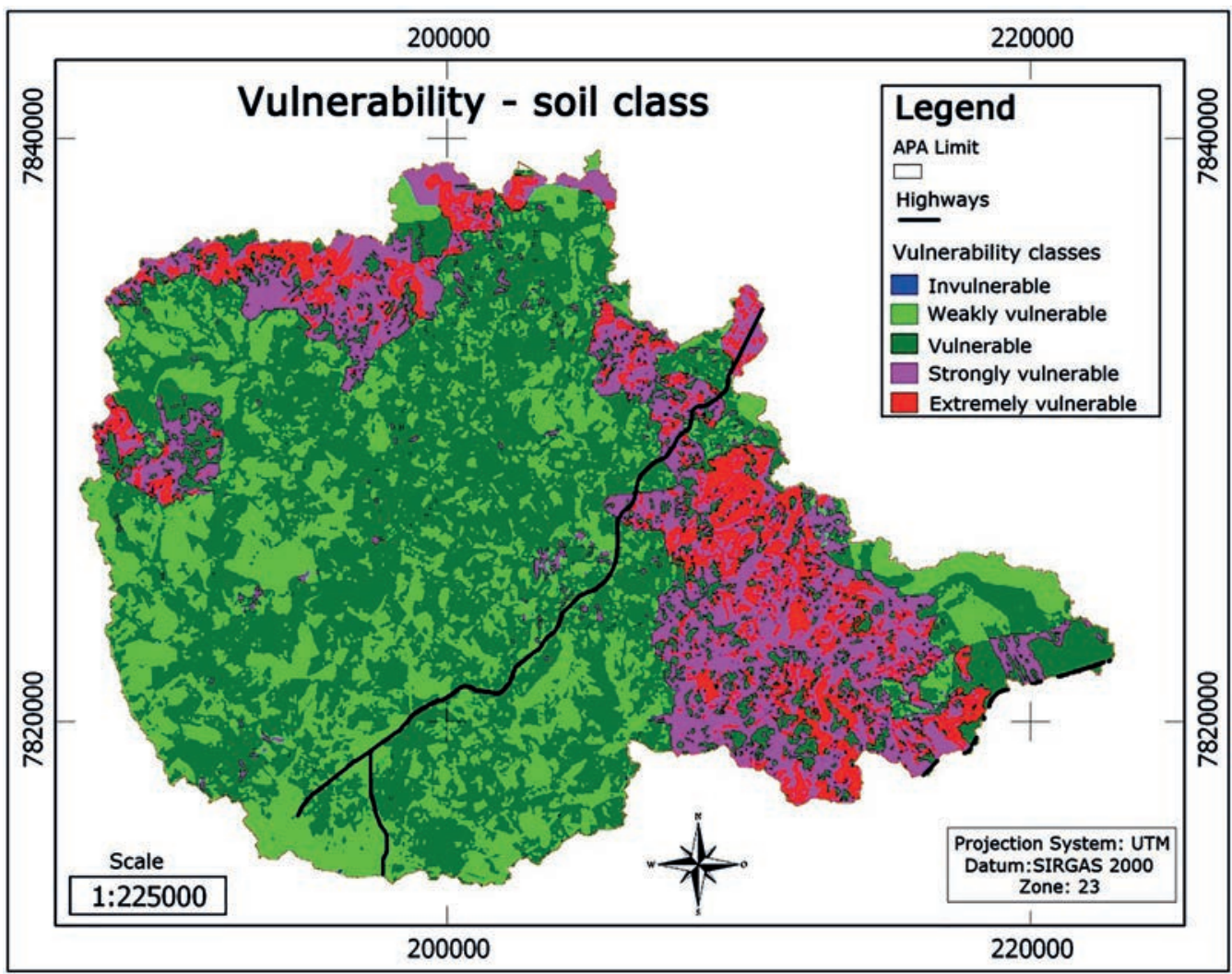

Figure 9 - Map of vulnerability of water resources in APA of Uberaba River.

Table 6 - Areas of vulnerability in the APA of Uberaba River.

\begin{tabular}{lcc}
\hline \multicolumn{1}{c}{ Risk classes } & Area $\left(\mathbf{k m}^{\mathbf{2}}\right)$ & Percentage of area (\%) \\
\hline Invulnerable & 0.00 & 0 \\
\hline Moderately Vulnerable & 138.438 & 26.6 \\
\hline Vulnerable & 259.690 & 49.9 \\
\hline Heavily Vulnerable & 85.340 & 16.4 \\
\hline Extremely Vulnerable & 37.061 & 7.1 \\
\hline Total & $\mathbf{5 2 0 , 5 2 9}$ & $\mathbf{1 0 0}$ \\
\hline
\end{tabular}

With this study it was possible to determine in the APA of Uberaba River the vulnera bility enviro nmental. According to morphometric and physical parameters of the catchment a rea and with the use of the Geographical information system it was possible to evaluate jointly the different levels of information.

Because it is a conservation a re a the area of Environmental protection, whose activities must be susta inable and use their water resources (ma in course of 
the Uberaba River) bein the supplying the population of Uberaba, thereis a need for studies that seek to assess the environmental quality of the existing natural resources as well as propose measures of preservation and conservation.

Environmental vulnera bility occ urs in the area studied, which indicates the risk of degradation of the na tural environment, related to soil erosion, loss of biodiversity, contamination of soil and water resources and vegetation cover loss aggravated by roads and misuse of the soil.

The dominant factor in the transport of contaminants to the water courses is the runoff, being the same powered by declivities, uses presented soil and physical characteristic s of the same. In this way the classes of soils prone to shallow streams generation given its characteristics, the

\section{References}

ABBASPOUR, M., MAHIN, A.S., ARJMANDY, R. and NAIMI, B., 2011. Integrated approach for land use suitability analysis. International Agrophysics, vol. 25, pp. 311-318. Available in: <http://www. old.internationalagrophysics.org/en/issues. html?stan=detail\&vol=25\&numer=4\&paper=946\&i=1 . Access: july 2014.

ABDALA, V.L., 2012. Diagnóstico hídrico do rio Uberaba - MG como subsídio para a gestão das áreas de conflito ambiental. 2012. 64 f. Tese (Doutorado em Agronomia) - Faculdade de Ciências Agrárias e Veterinárias, Universidade Estadual Paulista "Júlio de Mesquita Filho", Jaboticabal.

AKINCI, H., ÖZALP, A.Y. and TURGUT, B., 2012. Agricultural land use suitability analysis using GIS and AHP technique. Computers and Electronics in Agriculture, vol. 97, pp. 71-82. http://dx.doi. org/10.1016/j.compag.2013.07.006. topography, the distance of the courses of the rivers interfluvial (drainage density and uses data to soils) should be strongly considered as elements of decision making for the management of water resources of this area, in order to promote the ma intenance of them quantita tively and qua lita tively.

\section{Conclusion}

The use of multi-c riteria a nalysis applied to the study of vulnerability of water resourcescan be employed in several studies since there is a correlation to the factors involved.

Morphometric and physic al aspects of influence in basin environmental vulnera bility.

BANAI, R., 1993. Fuzziness in Geographical Information Systems: Contribution from the Analytic Hierarchy Process. International Journal of Geographical Information Science, vol. 7, no. 4, pp. 315-329. http://dx.doi.org/10.1080/02693799308901964.

BRASIL, 2000. Lei no 9.985 de 18 de julho de 2000. Regulamenta o art. 225, § 10, incisos I, II, III e VII da Constituição Federal, institui o Sistema Nacional de Unidades de Conservação da Natureza e dá outras providências. Brasília, DF. Available in: http://www. planalto.gov.br/ccivil_03/LEIS/L9985.htm. Access: Oct. 2014.

BRASIL, 2007. Ministério do Meio Ambiente. Vulnerabilidade Ambiental. Brasilia, $192 \mathrm{p}$.

BOTTERO, M., COMINO, E., DURIAVIG, M., FERRETTI, V. and POMARICO, S., 2013. The application of a Multicriteria Spatial Decision Support System (MCSDSS) for the assessment of biodiversity conservation in the Province of Varese (Italy). Land Use Policy, vol. 30, pp. 730-738. http://dx.doi.org/10.1016/j. landusepol.2012.05.015. 
CALIZAYA, A., MEIXNER, O., BENGTSSON, L. and BERNDTSSON, R., 2010. Multi-criteria Decision Analysis (MCDA) for Integrated Water Resources Management (IWRM) in the Lake Poopo Basin, Bolivia. Water Resources Management, vol. 24, pp. 2267-2289. http://dx.doi.org/10.1007/s11269009-9551-x.

CARDOSO, C.A., DIAS, H.C.T., SOARES, C.P.B. and MARTINS, S.V., 2006. Caracterização morfométrica da bacia hidrográfica do rio Debossan, Nova Friburgo, RJ. Revista Árvore, vol. 30, no. 2, Viçosa.

CHEN, Y. and PAYDAR, Z., 2012. Evaluation of potential irrigation expansion using a spatial fuzzy multi-criteria decision framework. Environmental Modelling \& Software, vol. 38, pp. 147-157. http://dx.doi. org/10.1016/j.envsoft.2012.05.010.

CHRISTOFOLETT, A., 1969. Análise morfométrica de bacias hidrográficas. Notícia Geomorfológica, vol. 18, no. 9, pp. 35-64.

CHISTOFOLETTI, A., 1980. Geomorfologia. São Paulo: Edgard Blüchler. 2 ed. 149p.

CRUZ, L.B.S., 2003. Diagnóstico ambiental da bacia hidrográfica do rio Uberaba - MG. 2003. 182 f. Tese (Doutorado em Engenharia Agrícola)- Faculdade de Engenharia Agrícola, Universidade Estadual de Campinas, Campinas.

DRAGINCIC, J., KORACB, N. and BLAGOJEVICA, B., 2015. Group multi-criteria decision making (GMCDM) approach for selecting the most suitable table grape variety intended for organic viticulture. Computers and Electronics in Agriculture, vol. 111, pp. 194-202. http://dx.doi.org/10.1016/j.compag.2014.12.023.

EMBRAPA, 1999. Empresa Brasileira de Pesquisa Agropecuária. Centro Nacional de Pesquisa de Solos. Sistema brasileiro de classificação de solos. Rio de Janeiro, 412 p.

EMBRAPA, 2006. Empresa Brasileira de Pesquisa Agropecuária. Centro Nacional de Pesquisa de Solos. Sistema Brasileiro de Classificação de solos. Rio de Janeiro, 2 ed., 306 p.

EASTMAN, J.R., 1998. IDRISI para Windows. Introdução aos exercícios tutoriais. Versão 2. Tradução: Heinrich Hasenack e Eliseu Weber. Porto Alegre, UFRGS Centro de Recursos IDRISI.

EASTMAN, J.R., 2012. IDRISI Selva Manual. Worcester, MA: Clark Labs, Clark University. 322 f. Available in: http://clarklabs.org/products/spanish-manual.cfm. Access: Jan. 2014.
FERREIRA, C.E.G., 2012. Sistema de Suporte à decisão espacial aplicado à análise da vulnerabilidade dos recursos hídricos na bacia Guapi-Macacu - RJ. 152 f. Dissertação (Mestrado em Engenharia de Computação) - Faculdade deEngenharia, Universidade do Estado do Rio de Janeiro, Rio de Janeiro.

GARFI, M., FERRER-MARTÍ, L., BONOLI, A. and TONDELLI, S., 2011. Multi-criteria analysis for improving strategic environmental assessment of water programmes.A case study in semi-arid region of Brazil, Journal of Environmental Management, vol. 92, pp. 665-675. http://dx.doi.org/10.1016/j. jenvman.2010.10.007.

HORTON, R., 1945. Erosional development of streams and their drainage basins: hidrophysical approach to quatitative morphology. Geological Society of American Bulletin. New York, vol. 56. pp. 807-813.

IBGE, 1974. Instituto Brasileiro de Geografia e Estatística. Cartas Topográficas. Folha SE 23-Y-C-IV (Uberaba). Brasília: IBGE. (Escala: 1:100.000). Available in: http://www.ibge.gov.br. Access: Jun. 2014.

JIANG, H. and EASTMAN, J.R., 2000. Application of fuzzy measures in multi-criteria evaluation in GIS, International Journal of Geographical Information Systems, vol. 14, no. 2, pp. 173-184. http://dx.doi. org/10.1080/136588100240903.

KAYA, T. and KAHRAMAN, C., 2011. Fuzzy multiple criteria forestry decision making based on an integrated VIKOR and AHP approach. Expert Systems with Applications, vol. 38, no. 6, pp. 7326-7333. http:// dx.doi.org/10.1016/j.eswa.2010.12.003.

LEPSCH, I.F., 2002. Formação e conservação dos solos. São Paulo: Oficina de Textos.

LIMA, W.P., 1986. Princípios de hidrologia florestal para o manejo de bacias hidrográficas. São Paulo: ESALQ, 242 p.

LIMA, L.A., SILVA JR., G.C., MENEZES, J.M. and SEABRA, V.S., 2009. Favorabilidade de Aqüíferos Fraturados, Bacia Hidrográfica do Rio São Domingos Estado do Rio de Janeiro. Anuário do Instituto de Geociências, vol. 32, no. 2. Rio de Janeiro: UFRJ, pp. 51-61. Available in: http://www.anuario.igeo.ufrj. br/2009_2/anuario_2009_v32_2_sumario.htm>. Access: July 2015.

MACHARIS, C., TURCKSIN, L. and LEBEAU, K., 2012. Multi actor multi criteria analysis (MAMCA) as a tool to support sustainable decisions: State of use. Decision Support Systems, vol. 54, pp. 610-620. http://dx.doi.org/10.1016/j.dss.2012.08.008. 
MALCZEWSKI, J., 1999. GIS and Multicriteria Decision Analysis, John Wiley and Sons. New York, p. 392. Available in: <http://books.google.pt/books?id=2Zd54x 4_2Z8C\&printsec=frontcover\&source=gbs_ge_

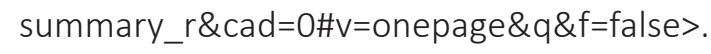

MARTIN-ORTEGA, J. and BERBEL, J., 2010. Using multi-criteria analysis to explore non-market monetary values of water quality changes in the context of the Water Framework Directive. Science of the Total Environment, vol. 408, no. 19, pp. 3990-3997. http://dx.doi.org/10.1016/j.scitotenv.2010.03.048.

MOTTA, L.H.S.O. and VALLADARES, G.S., 2011. Vulnerabilidade à degradação dos solos da Bacia do Acaraú, Ceará. Revista Ciência Agronômica, vol. 42, no. 1, pp. 39-50. Available in: <http://www. ccarevista.ufc.br/seer/index.php/ccarevista/article/ view/1041/533.

MUSA, K.A., AKHIR, J.M. and ABDULLAH, I., 2008. Groundwater Prediction Potential Zone in Langat Basin using the Integration of Remote Sensing and GIS.In: XVI Congresso Brasileiro de Águas Subterrâneas e XVII Encontro Nacional de Perfuradores de Poços. Anais... Natal: ABAS.

NISHIYAMA, L., 1989. Geologia do Município de Uberlândia e áreas adjacentes. Sociedade e Natureza, Uberlândia, vol. 1, no. 1, pp. 9-15.

NISHIYAMA, L., 1998. Procedimentos de mapeamento geotécnico como base paraanálises e avaliações ambientais do meio físico, em escala 1:100.000: aplicação no município de Uberlândia - MG. Tese (Doutorado em Geotecnia) - Universidade Federal de São Carlos, São Paulo.

OLIVEIRA, J.B., 2005. Pedologia aplicada. 2. ed. Piracicaba: FEALQ, $574 \mathrm{p}$.

PRADO, R. B., 2004. Geotecnologias aplicadas à análise espaço-temporal do uso e cobertura da terra e qualidade da água de Barra Bonita, SP, como suporte à gestão de recursos hídricos. $172 \mathrm{f}$. Tese (Doutorado em ciências das Engenharia Ambiental). Universidade de São Paulo, São Carlos, 2004. Available in: <http://www.teses.usp.br>. Access: Oct. 2014.

PINTO, R.C., 2010. Verificação de aptidão de áreas selecionadas para instalação de parque de lazer no Município de Paranaguá-PR utilizando-se de sistemas de informações geográficas. Geoingá: Revista do Programa de Pós-Graduação em Geografia, vol. 2, no. 1, pp. 83-104. Available in: http://periodicos.uem. br/ojs/index.php/Geoinga/article/view/14964/8398. Access: Jul. 2014.
PISSARRA, T.C.T., 2002. Análise da Bacia Hidrográfica do Córrego Rico na sub-região de Jaboticabal, SP: Comparação entre imagens TM-LANDSAT 5 e Fotografias aéreas verticais. $136 \mathrm{f}$. Tese (Doutorado em Produção Vegetal) Faculdade deCiências Agrárias e Veterinárias, Universidade Estadual Paulista, Jaboticabal.

PISSARRA, T.C.T., POLITANO, W. and FERRAUDO, A.S.. 2004. Avaliação de características morfométricas na relação solo-superfície da bacia hidrográfica do córrego Rico, Jaboticabal (SP). Revista Brasileira de Ciência do Solo, vol. 28, pp. 297-305. http://dx.doi. org/10.1590/S0100-06832004000200008.

ROCHA, J.S.M., 1977. Avaliação quantitativa da capacidade de uso da terra do estado do Rio Grande do Sul. 169 f. Tese (Livre Docência) - Universidade Federal deSanta Maria, Santa Maria.

ROCHA, J.S.M., 1997. Manual de projetos ambientais. Santa Maria: UFSM. 423p.

SAATY, T.L., 1980. The Analytic Hierarchy Process. Planning, Priority Setting, Resource Allocation. McGraw-HillUSA.

SANTOS, A.F., 2004. Morfometria da microbacia hidrográfica do Ribeirão Faxinal Botucatu - SP e alterações em suas áreas de biomassa no período de 1972 a 2000. 59 f. Dissertação (Mestrado em Agronomia)- Faculdade de Ciências Agronômicas, Universidade Estadual Paulista "Júlio de Mesquita Filho", Botucatu.

SENER, E., DAVRAZ, A. and OZCELIK, M. An Integration of GIS and remote sensing ingroundwater investigations: A case study in Burdur, Turkey. Hydrogeology Journal, p. 826-834. Available in: http:// www.springerlink.com/content/c3ha1w4225f91qrj. Access: Jan. 2015.

SOUZA, A.L.N., FERNANDES, V.H., CARVALHO, L.G. and ANTUNES, M.A.H., 2003. Ferramentas de geoprocessamento para estudos de potencial hidrogeológico. In: XXI Congresso Brasileiro de Cartografia, SBC, Belo Horizonte. Anais... Belo Horizonte.

SOUZA, T.A.R., HISSA, L.B.V., MICHEL, R.F.M. and MORAIS A.M.L., 2009. Análise de Multicritério aplicada ao diagnóstico do risco ambiental do transporte rodoviário de produtos perigosos: um estudo de caso sobre a BR-381. In: XIV Simpósio Brasileiro de Sensoriamento Remoto, 2009, Natal. Anais eletrônicos... INPE. Natal, RN. Available in: http://marte. sid.inpe.br/col/dpi.inpe.br/sbsr@80/2008/11.18.01.02/ doc/4465-4472.pdf. Access: Jun. 2015. 
UFV, 2010. Universidade Federal de Viçosa. Fundação Centro Tecnológico de Minas Gerais; Universidade Federal de Lavras; Fundação Estadual do Meio Ambiente. Mapa de solos do Estado de Minas Gerais. Belo Horizonte. p. 35-49.

VALLE JUNIOR, R.F., 2008. Diagnóstico de áreas de risco de erosão e conflito de uso dos solos na bacia do rio Uberaba. 222 f. Tese (Doutorado em Agronomia) - Faculdade de Ciências Agrárias e Veterinárias, Universidade Estadual Paulista "Júlio de Mesquita Filho", Jaboticabal.

VALLE JUNIOR, R.F., GALBIATTI, J.A., MARTINS FILHO, M.V. and PISSARRA, T.C.T., 2010. Potencial de erosão da bacia do Rio Uberaba. Engenharia Agrícola, vol. 30, pp. 897-908. http://dx.doi.org/10.1590/s010069162010000500012.

VALLE JUNIOR, R.F., VARANDAS, S.G.P., SANCHES FERNANDES, L.F. and PACHECO, F.A.L., 2014. Environmental land use conflicts: a threat to soil conservation. Land Use Policy, vol. 41, pp. 172-185. http://dx.doi.org/10.1016/j.landusepol.2014.05.012.

VALLE JUNIOR, R.F., VARANDAS, S.G.P., SANCHES FERNANDES, L.F. and PACHECO, F.A.L. Multi Criteria Analysis for the monitoring of aquifer vulnerability: A scientific tool in environmental policy. Environmental Science \& Policy, vol. 48, pp. 250-264. http://dx.doi. org/10.1016/j.envsci.2015.01.010.
VELDKAMP, A. and LAMBIN, E.F., 2001. Predicting landuse change, Agriculture, Ecosystems \& Environment, vol. 85, pp. 1-6. http://dx.doi.org/10.1016/S01678809(01)00199-2.

VIEIRA, C.A.O., 2000. Accuracy of remotely sensing classification of agricultural crops: a comparative study. P. 327. Thesis (Doctor of Philosophy in Physical Geography)- University of Nottingham, Nottingham.

VILLELA, S.M. and MATTOS, A., 1975. Hidrologia aplicada. São Paulo: McGraw-Hill do Brasil. 245 p.

YU, J., CHEN, Y. and WU, J.P., 2009. Cellular Automata and GIS based landuse suitability simulation for irrigated agriculture. In: 18th World IMACS/MODSIM Congress, Cairns, Australia, p. 7. http://metronu.ulb. ac.be/imacs/cairns/18/yu_j.pdf.

ZADEH L.A., 1965. Fuzzy sets. Inf. Control, vol. 8, pp. 338-353.Available in: http://www.cs.berkeley. edu/ zadeh/papers/Fuzzy\%20SetsInformation\%20 and\%20Control-1965.pdf.

ZHANG, J., WANG, K., CHEN, X. and ZHU, W., 2011. Combining a Fuzzy Matter-Element Model with a Geographic Information System in Eco-Environmental Sensitivity and Distribution of Land Use Planning. Int. J. Environ. Res. Public Health, vol. 8, pp. 12061221. http://dx.doi.org/10.3390/ijerph8041206. 